OPEN ACCESS

Edited by:

Jorge Rodriguez-Celma, John Innes Centre, United Kingdom

Reviewed by:

Cristiana Sbrana,

Italian National Research Council, Italy Naoko Ohkama-Ohtsu,

Tokyo University of Agriculture and Technology, Japan

*Correspondence: Chun-Qin Zou zcq0206@cau.edu.cn

Specialty section: This article was submitted to Plant Nutrition, a section of the journal Frontiers in Plant Science

Received: 15 September 2020 Accepted: 03 November 2020 Published: 03 December 2020

Citation:

Yu B-G, Chen X-X, Cao W-Q, Liu Y-M and Zou C-Q (2020) Responses in Zinc Uptake of Different Mycorrhizal and Non-mycorrhizal Crops to Varied Levels of Phosphorus and Zinc Applications.

Front. Plant Sci. 11:606472. doi: 10.3389/fpls.2020.606472

\section{Responses in Zinc Uptake of Different Mycorrhizal and Non-mycorrhizal Crops to Varied Levels of Phosphorus and Zinc Applications}

\author{
Bao-Gang Yu, Xiu-Xiu Chen, Wen-Qing Cao, Yu-Min Liu and Chun-Qin Zou* \\ College of Resources and Environmental Sciences, National Academy of Agriculture Green Development, Key Laboratory \\ of Plant-Soil Interactions, Ministry of Education, China Agricultural University, Beijing, China
}

Negative effects of high phosphorus (P) application on zinc $(Z n)$ nutrition have been observed in many crops. This study investigated the $Z n$ responses of three typical crops to varied $\mathrm{P}$ and $\mathrm{Zn}$ applications. A pot experiment was conducted using two mycorrhizal crops (maize and soybean) and one non-mycorrhizal crop (oilseed rape) under three levels of $\mathrm{P}$, two levels of $\mathrm{Zn}$, and two levels of benomyl. Results showed that $P$ application significantly decreased shoot and root Zn concentrations, Zn uptake, and $Z n$ acquisition efficiency ( $Z n A E)$ of the three crops irrespective of $Z n$ rate, and that these reductions were greater for maize and soybean than for oilseed rape. $\mathrm{Zn}$ application alleviated the $\mathrm{P}$ inhibition of $\mathrm{Zn}$ uptake in the three crops. The arbuscular mycorrhizal fungi (AMF) colonization of maize and soybean contributed most to the negative effects of increasing P application on Zn uptake, explaining 79-89 and 64-69\% of the effect, respectively. For oilseed rape, root dry weight and root $\mathrm{Zn}$ concentration explained $90 \%$ of the decrease in Zn uptake caused by $\mathrm{P}$ application. These results suggest that there is another pathway in addition to the mycorrhizal pathway regulating $\mathrm{Zn}$ uptake under mediation by $P$ supply.

Keywords: phosphorus, zinc uptake, mycorrhizal and non-mycorrhizal crops, maize, soybean, oilseed rape

\section{INTRODUCTION}

Zinc $(\mathrm{Zn})$ is an essential micronutrient in plant growth and development and also plays a vital role in protecting the health of the brain and nervous system of infants and children (Cakmak, 2008). Almost 50\% of cereal crops are cultivated in Zn-deficient soil, which contributes to plant and human Zn malnutrition (Zou et al., 2012; Shahzad et al., 2014). According to a report from the WHO (2016), Zn deficiency affects one-third of people worldwide and is particularly prevalent in developing countries.

High application of phosphorus (P) fertilizer is the main reason for low $\mathrm{Zn}$ concentration in cereal crops. Many studies have shown that $\mathrm{Zn}$ concentration in tissue and grain is significantly 
decreased by P application (Zhang et al., 2012; Chen et al., 2017). The complex negative interplay between $P$ and $Z n$ has drawn much attention since the 1960s, but there have been no convincing explanations of the mechanism of this antagonism until recently (Stukenholtz et al., 1966; Bouain et al., 2014b).

The negative effects of higher $\mathrm{P}$ application on $\mathrm{Zn}$ concentration in grain mainly occur in the following processes: uptake, translocation, and remobilization. Zhang et al. (2015, 2017a,b) and Zhang W. et al. (2016) demonstrated that P application significantly affected root uptake of $\mathrm{Zn}$, whereas $\mathrm{Zn}$ translocation from roots to shoots and remobilization efficiency were not consistently affected. The significant decrease in $\mathrm{Zn}$ uptake is the key factor explaining the antagonistic interaction between P and Zn (Singh et al., 1986; Yang et al., 2011). Nonetheless, understanding of how $\mathrm{P}$ application influences root uptake of $\mathrm{Zn}$ is limited.

Arbuscular mycorrhizal fungi (AMF) can form a mutualistic relationship with $80 \%$ of terrestrial plants (including most crops), in which the extensive extraradical mycelium in the soil enhances immobile nutrient (such as $\mathrm{P}$ and $\mathrm{Zn}$ ) uptake for the host plant in exchange for photosynthesis products from the plant for the fungus (Smith et al., 2003; Cavagnaro, 2008). A meta-analysis by Lehmann et al. (2014) showed that AMF had positive effects on $\mathrm{Zn}$ concentration in fruit (grain), shoot, and root of plants. A field experiment conducted on calcareous soils indicated that $\mathrm{Zn}$ uptake of wheat increased linearly with increases in AMF colonization (Hui et al., 2019). However, because AMF colonization is negatively correlated with $\mathrm{P}$ application, the quantity of $\mathrm{Zn}$ taken by AMF can be greatly reduced by $\mathrm{P}$ application (Zhang et al., 2017a). A pot and hydroponics experiment suggested that the only reason for the reduction in tissue $\mathrm{Zn}$ concentration of wheat caused by $\mathrm{P}$ application was the reduction of AMF colonization (Ova et al., 2015). However, Watts-Williams et al. (2013) conducted a pot experiment with mycorrhiza-defective tomato $(\mathrm{rmc})$ and its wild-type progenitors (76R) and found that $\mathrm{Zn}$ concentration in shoots and roots of $r m c$ and 76R was significantly decreased by $\mathrm{P}$ application. A solution culture experiment (i.e., mycorrhiza-defective environment) also showed that root $\mathrm{Zn}$ uptake of lettuce significantly decreased with increasing $P$ concentration in the nutrient solution (Bouain et al., 2014a). That is, the negative effects of higher $P$ application on $\mathrm{Zn}$ uptake can be partially explained by the AMF pathway. Overall, the mycorrhizal pathway has been considered a vital factor explaining the antagonistic interaction between $\mathrm{P}$ and $\mathrm{Zn}$. However, the contribution of AMF colonization to the decrease in $\mathrm{Zn}$ uptake caused by $\mathrm{P}$ application among mycorrhizal crops remains unclear.

Plant species with different root morphologies or physiological characteristics can respond differently to AMF (Tawaraya, 2003). Tran et al. (2019) examined the responses of 15 plant species in pots and found large variation in crop growth and nutritional responses to AMF, i.e., growth and $\mathrm{Zn}$ nutrition responses vary among different AMF colonization plants. Moreover, a metaanalysis conducted by Hoeksema et al. (2010) suggested that $\mathrm{C}_{4}$ grasses (e.g., maize) respond more positively to AMF inoculation than $C_{3}$ grasses (e.g., soybean). To the best of our knowledge, many studies have focused primarily on the responses of different plant species, crop genotype growth, or a single type of nutrition to AMF, but the negative effects of higher $\mathrm{P}$ application on $\mathrm{Zn}$ concentration and $\mathrm{Zn}$ uptake of different mycorrhizal and nonmycorrhizal crops under the same growth conditions, which is very important for elucidating the $\mathrm{Zn}$ uptake pathway mediated by $\mathrm{P}$ application, have not yet been reported.

As representatives of main cereal crops, legume crops, and oil-producing crops, maize (Zea mays L.), soybean (Glycine max L.), and oilseed rape (Brassica napus L.) are important dietary sources of calories, proteins, and micronutrients. Thus, it is valuable to clarify the mechanisms of $\mathrm{Zn}$ uptake as mediated by $\mathrm{P}$ application of these three crops. Among these crops, both maize and soybean are highly mycorrhizal crops under current agricultural management practices, but oilseed rape is considered a non-mycorrhizal crop (Buee et al., 2000; Chu et al., 2020; Qin et al., 2020). Besides, as a general fungicide, benomyl can effectively suppress AMF colonization, in which it is considered as an ideal method to evaluate mycorrhizal responsiveness (Yang et al., 2014; Qiao et al., 2019). Therefore, we selected two typical mycorrhizal crops, maize and soybean, and one nonmycorrhizal crop, oilseed rape, to study the different responses of $\mathrm{Zn}$ concentration and $\mathrm{Zn}$ uptake to various levels of $\mathrm{P}, \mathrm{Zn}$, and benomyl application and to clarify the contributions of potential factors to the antagonistic interaction of $\mathrm{P}$ and $\mathrm{Zn}$. We hypothesized that $\mathrm{P}$ application significantly decreased $\mathrm{Zn}$ uptake of mycorrhizal and non-mycorrhizal crops, the decreases in $\mathrm{Zn}$ uptake of mycorrhizal crops caused by $\mathrm{P}$ application were mainly attributed to AMF colonization decline, and the decrease of non-mycorrhizal crops was mainly due to root system architecture.

\section{MATERIALS AND METHODS}

\section{Experimental Design}

A pot experiment was conducted from March to May 2018 at China Agriculture University (CAU). The soil used in this experiment was from the Quzhou Experiment Station $\left(36.9^{\circ} \mathrm{N}\right.$, $115.0^{\circ} \mathrm{E}$ ) of CAU. The initial soil $\mathrm{pH}$ was 8.01 , and soil available $\mathrm{Zn}$ (DTPA-Zn) and P concentrations (Olsen-P) were 0.93 and $9.97 \mathrm{mg} \mathrm{kg}^{-1}$, respectively (The corresponding analysis methods are shown in section "Harvesting and Analyses"). Two $\mathrm{Zn}$ levels (0 and $30 \mathrm{mg} \mathrm{Zn} \mathrm{kg}{ }^{-1}$ soil) as $\mathrm{ZnSO}_{4} \cdot 7 \mathrm{H}_{2} \mathrm{O}$ and three P levels $\left(0,200\right.$, and $600 \mathrm{mg} \mathrm{P} \mathrm{kg}^{-1}$ soil) in the form of $\mathrm{Ca}\left(\mathrm{H}_{2} \mathrm{PO}_{4}\right)_{2}$ were applied in this experiment. To establish different AMF colonization, two benomyl levels ( 0 and $0.4 \mathrm{~g} \mathrm{~kg}^{-1}$ soil) were used based on a previous study (Fitter and Nichols, 1988). In addition, $200 \mathrm{mg}$ nitrogen $(\mathrm{N}) \mathrm{kg}^{-1}$ soil in the form of urea and $200 \mathrm{mg} \mathrm{K}_{2} \mathrm{O} \mathrm{kg}^{-1}$ soil in the form of $\mathrm{K}_{2} \mathrm{SO}_{4}$ were applied uniformly to all treatments before sowing. Benomyl was dissolved in $1 \mathrm{~L}$ distilled water and total irrigated four times (once every 2 -week period). An equivalent amount of distilled water was irrigated in no-benomyl-addition treatments to create a similar soil moisture condition. Each pot contained $3.5 \mathrm{~kg}$ soil. All crops were arranged in a glasshouse with a randomized complete block design with three replicates and were watered with distilled water as needed. 
Maize (Z. mays L., cv. Zhengdan 958), soybean (G. max L., cv. Zhonghuang 37), and oilseed rape (B. napus L., cv. Meiyou 758) seeds were planted in this experiment. Five germinated maize and soybean seeds and eight germinated oilseed rape seeds were transferred to pots after germination. At the three-leaf stage of maize, each pot was thinned to three plants. Soybean and oilseed rape were thinned to two and five plants per pot within 1 week after sowing, respectively.

\section{Harvesting and Analyses}

Seven weeks after sowing, the shoots and roots of each plant were harvested. Shoots were cut off at ground level using stainless steel scissors. All shoot and root samples were washed three times with tap water and distilled water, respectively. Fresh root subsamples with a mass of $0.5 \mathrm{~g}$ were used to evaluate arbuscular mycorrhizal colonization. Segments with a length of $1 \mathrm{~cm}$ were soaked in $\mathrm{KOH}(10 \%), \mathrm{HCl}(2 \%)$, trypan blue $(0.05 \%)$, and acidic glycerol, respectively (Koske and Gemma, 1989). Then, arbuscular mycorrhizal colonization was quantified using the magnified intersections method (McGonigle et al., 1990).

Shoots and remaining roots were oven-dried at $60-65^{\circ} \mathrm{C}$ to constant weight to record dry weight and then were ground with a stainless-steel grinder for $\mathrm{Zn}$ nutrition analyses. The plant samples were digested with $\mathrm{HNO}_{3}-\mathrm{H}_{2} \mathrm{O}_{2}$ using a microwaveaccelerated reaction system (CEM, Matthews, NC, United States), and the $\mathrm{Zn}$ concentration in the digestate was analyzed by inductively coupled plasma optical emission spectroscopy (ICPOES; OPTIMA 3300 DV; Perkin-Elmer, United States). Standard materials (IPE126) from Wageningen Evaluation Programs for Analytical Laboratories (WEPAL; Wageningen University, Netherlands) were used to check the $\mathrm{Zn}$ concentrations in shoots and roots.

Soil samples were collected, air-dried, and then passed through a $1 \mathrm{~mm}$ plastic sieve for analyses of available $\mathrm{Zn}$ and $\mathrm{P}$ concentrations. The available $\mathrm{Zn}$ concentration was extracted using $5 \mathrm{mmol} \mathrm{L}^{-1}$ diethylenetriaminepentaacetic acid (DTPA) and analyzed by ICP-OES (OPTIMA 3300 DV; Perkin-Elmer, United States) (Lindsay and Norvell, 1978). The soil available $\mathrm{P}$ concentration was extracted using $0.5 \mathrm{~mol} \mathrm{~L}^{-1} \mathrm{NaHCO}_{3}$ and analyzed using a spectrophotometer (Olsen, 1954). Soil pH (1:2.5 w/v in water) was determined by a $\mathrm{pH}$ meter (PB-10; Sartorius, Germany).

\section{Calculation and Statistical Analyses}

$\mathrm{Zn}$ acquisition efficiency ( $\mathrm{ZnAE}$ ) was calculated according to $\mathrm{Zhu}$ et al. (2001):

\section{$\mathrm{ZnAE}=$ total $\mathrm{Zn}$ accumulation/root dry weight.}

For further analyses of the effects of AMF on Zn nutrition, mycorrhizal $\mathrm{Zn}$ responsiveness (MZnR) was calculated according to Gao et al. (2007):

$\mathrm{MZnR}=\left(\left[\mathrm{Zn}\right.\right.$ accumulation $_{B 0}-\mathrm{Zn}$ accumulation $\left._{B 0 \cdot 4}\right] / \mathrm{Zn}$ accumulation $\left._{B 0 \cdot 4}\right) \times 100$

where $\mathrm{Zn}$ accumulation ${ }_{B 0.4}$ and $\mathrm{Zn}$ accumulation aco $_{B 0}$ represent the total $\mathrm{Zn}$ accumulation of crops treated with and without benomyl addition, respectively.
Three-way analyses of variance (ANOVAs) were conducted to test the main effects of $\mathrm{P}, \mathrm{Zn}$, and benomyl additions and their interactions on the dry weights of shoots and roots, $\mathrm{Zn}$ concentration in shoots and roots, total $\mathrm{Zn}$ accumulation, $\mathrm{ZnAE}$, and AMF colonization. Similarly, two-way ANOVAs were carried out to test the main effects of $\mathrm{P}$ and $\mathrm{Zn}$ applications and their interactions on MZnR. Following ANOVA, means for different $P$ levels were compared within $\mathrm{Zn}$ and benomyl application levels using SAS software (version 8.0). SPSS software (version 26.0) was used to perform path coefficient analyses to evaluate the contributions of potential factors to the antagonistic interaction between $\mathrm{P}$ and $\mathrm{Zn}$.

\section{RESULTS}

\section{Shoot and Root Dry Weights}

$\mathrm{P}$ and $\mathrm{Zn}$ applications significantly increased shoot and root dry weights of maize, soybean, and oilseed rape. Benomyl addition significantly decreased shoot and root dry weights of maize and soybean but not of oilseed rape. There were significant interactions between $\mathrm{P}$ and $\mathrm{Zn}$ application levels for the three crops (Table 1). When no $\mathrm{Zn}$ was applied, irrespective of the level of benomyl addition, shoot and root dry weights of maize, soybean, and oilseed rape increased with $\mathrm{P}$ application from 0 to $200 \mathrm{mg} \mathrm{kg}^{-1}$ and then decreased with further $\mathrm{P}$ application to $600 \mathrm{mg} \mathrm{kg}^{-1}$ (Table 1). When $\mathrm{Zn}$ was applied at $30 \mathrm{mg} \mathrm{kg}^{-1}, \mathrm{P}$ application (200 and $600 \mathrm{mg} \mathrm{kg}^{-1}$ ) led to 24-42, 22-41, and 20$33 \%$ increases in the shoot dry weights of maize, soybean, and oilseed rape compared with no $\mathrm{P}$ application, respectively, when no benomyl was added. There were similar increases in shoot and root dry weights when $30 \mathrm{mg} \mathrm{Zn} \mathrm{kg}^{-1}$ and $0.4 \mathrm{~g} \mathrm{~kg}^{-1}$ benomyl was added (Table 1).

\section{Zn Concentration, Accumulation, and Acquisition Efficiency}

Zn concentration in shoots and roots was significantly decreased in all crops by $\mathrm{P}$ application regardless of $\mathrm{Zn}$ and benomyl additions (Figure 1). When no $\mathrm{Zn}$ was applied, total $\mathrm{Zn}$ accumulation (Figures 2A,B) and ZnAE (Figures 2C,D) were significantly decreased in all crops by $\mathrm{P}$ application, and these traits in maize and soybean but not in oilseed rape were also significantly decreased by $\mathrm{P}$ application when $30 \mathrm{mg} \mathrm{Zn} \mathrm{kg}-1$ was added (Figure 2). Benomyl addition also decreased $\mathrm{Zn}$ concentration in shoots and roots, total $\mathrm{Zn}$ accumulation, and $\mathrm{ZnAE}$ in maize and soybean but not in oilseed rape (Table 2). Irrespective of $\mathrm{P}$ and benomyl additions, $\mathrm{Zn}$ application obviously increased these three traits in all crops (Table 2). Compared with no $\mathrm{P}$ application, $\mathrm{P}$ application led to 43-63, 29-60, and $19-31 \%$ decreases in $\mathrm{Zn}$ concentration in shoots of maize, soybean, and oilseed rape when no $\mathrm{Zn}$ or benomyl was added (Figure 1A). There were similar decreases in $\mathrm{Zn}$ concentration in the roots of all three crops (Figures 1C,D). Meanwhile, $600 \mathrm{mg} \mathrm{P} \mathrm{kg}-1$ application decreased the total $\mathrm{Zn}$ accumulation of maize, soybean, and oilseed rape by 55,54 , and $31 \%$ compared with no $\mathrm{P}$ application when no $\mathrm{Zn}$ or benomyl was added, respectively. When $30 \mathrm{mg} \mathrm{Zn} \mathrm{kg}^{-1}$ was added but 
TABLE 1 | Shoot and root dry weights of maize, soybean, and oilseed rape affected by P application (P), Zn application (Zn), and benomyl addition (B), respectively.

\begin{tabular}{|c|c|c|c|c|c|c|c|c|}
\hline \multirow[t]{2}{*}{ B level $\left(\mathbf{g ~ k g}^{-1}\right)$} & \multirow[t]{2}{*}{ Zn level $\left(\mathbf{m g ~ k g}^{-1}\right)$} & \multirow[t]{2}{*}{ P level (mg kg $\left.{ }^{-1}\right)$} & \multicolumn{3}{|c|}{ Shoot dry weight (g plant ${ }^{-1}$ ) } & \multicolumn{3}{|c|}{ Root dry weight (g plant ${ }^{-1}$ ) } \\
\hline & & & Maize & Soybean & Oilseed rape & Maize & Soybean & Oilseed rape \\
\hline \multirow[t]{6}{*}{0} & 0 & 0 & $4.3 b$ & $2.8 b$ & $2.3 b$ & $0.54 b$ & $0.35 b$ & $0.29 b$ \\
\hline & & 200 & $5.4 \mathrm{a}$ & $3.4 \mathrm{a}$ & $2.7 a$ & $0.63 a$ & $0.40 a$ & $0.32 a b$ \\
\hline & & 600 & $5.1 \mathrm{ab}$ & $3.1 \mathrm{a}$ & $2.3 a b$ & $0.56 \mathrm{ab}$ & $0.39 a b$ & $0.30 b$ \\
\hline & 30 & 0 & $4.6 c$ & $2.9 \mathrm{c}$ & $2.4 b$ & $0.56 b$ & $0.36 b$ & $0.30 b$ \\
\hline & & 200 & $5.7 \mathrm{~b}$ & $3.6 b$ & $2.9 a$ & 0.69ab & $0.43 a$ & $0.35 a$ \\
\hline & & 600 & $6.5 a$ & $4.1 \mathrm{a}$ & $3.2 \mathrm{a}$ & $0.72 a$ & $0.44 a$ & $0.38 a$ \\
\hline \multirow[t]{6}{*}{0.4} & 0 & 0 & $3.4 b$ & $2.6 b$ & $2.3 b$ & $0.36 b$ & $0.29 b$ & $0.27 \mathrm{~b}$ \\
\hline & & 200 & $4.7 \mathrm{a}$ & $3.0 \mathrm{a}$ & $2.5 a$ & $0.44 a$ & $0.34 a$ & $0.30 a$ \\
\hline & & 600 & $4.6 a$ & $2.8 \mathrm{ab}$ & $2.5 a b$ & $0.41 \mathrm{ab}$ & $0.31 \mathrm{ab}$ & $0.28 b$ \\
\hline & 30 & 0 & $3.7 \mathrm{c}$ & $2.8 \mathrm{c}$ & $2.4 b$ & $0.40 c$ & $0.30 b$ & $0.31 b$ \\
\hline & & 200 & $5.0 \mathrm{~b}$ & $3.1 b$ & $2.9 a$ & $0.54 b$ & $0.36 a b$ & $0.32 a b$ \\
\hline & & 600 & $6.0 a$ & $3.5 \mathrm{a}$ & $3.0 \mathrm{a}$ & $0.65 a$ & $0.38 a$ & $0.34 a$ \\
\hline \multicolumn{9}{|l|}{ Source of variation } \\
\hline$P$ level $(P)$ & & & $\star \star \star ~$ & $\star \star \star$ & $\star \star \star ~$ & $\star \star \star \star ~$ & $\star \star \star ~$ & $\star \star$ \\
\hline Zn level (Zn) & & & $\star \star \star ~$ & $\star \star \star ~$ & 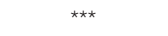 & 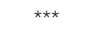 & 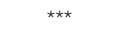 & 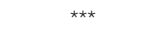 \\
\hline B level (B) & & & 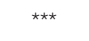 & $\star \star \star$ & ns & 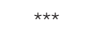 & 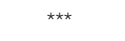 & ns \\
\hline$P \times Z n$ & & & $\star \star$ & $\star \star \star \star$ & $\star \star \star \star ~$ & $\star \star$ & * & $\star \star$ \\
\hline$P \times B$ & & & ns & $\star \star$ & ns & ns & ns & ns \\
\hline $\mathrm{Zn} \times \mathrm{B}$ & & & ns & ns & ns & ns & ns & ns \\
\hline$P \times Z n \times B$ & & & ns & ns & ns & ns & ns & ns \\
\hline
\end{tabular}

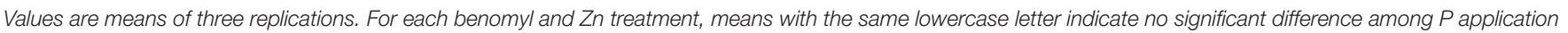
levels $(P<0.05)$.

${ }^{*},{ }^{* *}$, and ${ }^{* * *}$ significance at $P<0.05,0.01$, and 0.001 , respectively.

ns, no significance, $P>0.05$.

no benomyl, the total $\mathrm{Zn}$ accumulation of maize and soybean decreased by 24 and $14 \%$ due to application of $600 \mathrm{mg} \mathrm{P} \mathrm{kg}^{-1}$ (Figures 2A,B). The ZnAEs of maize, soybean, and oilseed rape without $\mathrm{Zn}$ or benomyl addition were reduced by $32-56$, $31-52$, and $15-35 \%$ by 200 and $600 \mathrm{mg} \mathrm{P} \mathrm{kg}{ }^{-1}$ applications, respectively (Figures 2C,D). More interestingly, the $\mathrm{ZnAE}$ of maize was higher than that of soybean, followed by oilseed rape (Figures 2C,D).

\section{AMF Colonization and MZnR}

No AMF colonization was detected in root segments of oilseed rape in any treatment (data not shown). The addition of $\mathrm{P}, \mathrm{Zn}$, and benomyl significantly decreased AMF colonization of maize and soybean (Table 2). There were significant (Table 2) three-way interactions among $\mathrm{P}, \mathrm{Zn}$, and benomyl treatments of both maize and soybean. Compared with no $\mathrm{P}$ application, $\mathrm{P}$ application led to $54-70$ and $37-60 \%$ decreases in AMF colonization of maize and soybean when no $\mathrm{Zn}$ or benomyl was added, respectively. The same decreases were observed in maize and soybean at other $\mathrm{Zn}$ and benomyl addition levels (Figure 3). As there were no significant differences in total $\mathrm{Zn}$ accumulation of oilseed rape between the no benomyl and the $0.4 \mathrm{~g} \mathrm{~kg}^{-1}$ benomyl treatments (Table 2), only the MZnR values of maize and soybean were calculated. P and $\mathrm{Zn}$ applications significantly decreased the MZnRs of three crops (Table 3). P application decreased that of maize by $45 \%$ when no $\mathrm{Zn}$ was applied and by $36 \%$

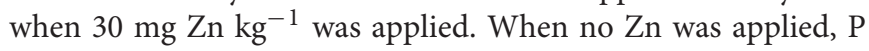

application significantly decreased the MZnR of soybean by $40 \%$, but there were no significant differences for the $30 \mathrm{mg} \mathrm{Zn} \mathrm{kg}^{-1}$ treatment (Table 3). In addition, AMF colonization and MZnR were consistently higher in maize than in soybean (Figure 3 and Table 3).

\section{Correlations Between Total Zn Accumulation and Root $\mathbf{Z n}$ Concentration, Root Dry Weight, and AMF Colonization}

We selected total $\mathrm{Zn}$ accumulation as the dependent variable and seven independent variables (shoot dry weight, root dry weight, shoot $\mathrm{Zn}$ concentration, root $\mathrm{Zn}$ concentration, AMF colonization, soil DTPA-Zn concentration, and soil Olsen$\mathrm{P}$ concentration) to uncover how and to what extent the independent variables influenced the total $\mathrm{Zn}$ accumulation of each crop; however, only root dry weight, root $\mathrm{Zn}$ concentration, and AMF colonization entered into the analyses process for the three crops (Table 4). Overall, when no $\mathrm{Zn}$ was applied, AMF colonization explained $89 \%$ of the total $\mathrm{Zn}$ accumulation of maize; AMF colonization, root dry weight, and root $\mathrm{Zn}$ concentration explained $90 \%$ of the total accumulation of soybean; and root dry weight and root $\mathrm{Zn}$ concentration explained $90 \%$ of the total accumulation of oilseed rape. When $\mathrm{Zn}$ was applied at $30 \mathrm{mg} \mathrm{kg}^{-1}$, AMF colonization and root dry weight explained $88 \%$ of the total accumulation 

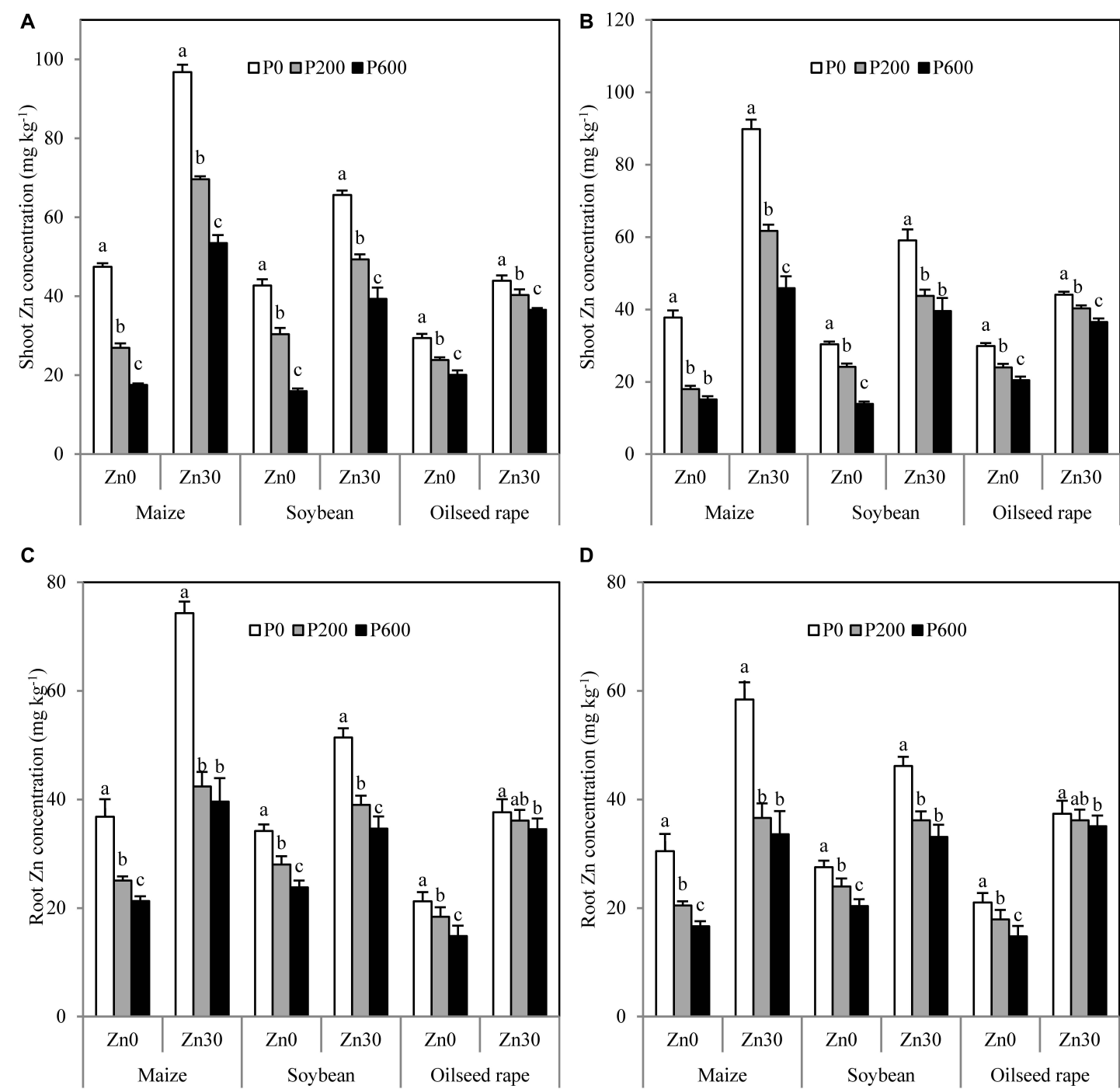

FIGURE 1 | Zn concentration in shoots and roots of maize, soybean, and oilseed rape affected by P and Zn applications without benomyl (A,C) and with $0.4 \mathrm{~g}$ benomyl $\mathrm{kg}^{-1}$ soil (B,D) addition, respectively. Values are means of three replications. The same lowercase letter indicates no significant difference among $\mathrm{P}$ application levels $(P<0.05)$. Zn0 and Zn30 represent 0 and $30 \mathrm{mg} \mathrm{Zn} \mathrm{kg}^{-1}$ soil rates, respectively. P0, P200, and P600 represent 0,200 , and 600 mg P kg ${ }^{-1}$ soil rates, respectively.

of maize, AMF colonization explained $64 \%$ of the total accumulation of soybean, and root dry weight and root $\mathrm{Zn}$ concentration explained $92 \%$ of the total accumulation of oilseed rape (Table 4 ).

\section{DISCUSSION}

\section{Effect of P Application on Zn Concentration and Uptake}

$\mathrm{P}$ application significantly decreased the $\mathrm{Zn}$ concentration of both maize and soybean, consistent with previous reports (Izsáki, 2014; Zhang et al., 2017a). It is worth noting that significant decreases in $\mathrm{Zn}$ concentration in shoots and roots with increasing $\mathrm{P}$ application were also observed in non-mycorrhizal crop, oilseed rape (Figure 1). This is consistent with previous research that showed that $\mathrm{Zn}$ concentrations in crambe (Crambe abyssinica Hochst, i.e., a non-mycorrhizal crop) significantly decreased with increasing $\mathrm{P}$ application (Cihacek et al., 1993). Considering the large changes in biomass in response to $\mathrm{P}$ application, the responses of total $\mathrm{Zn}$ accumulation due to $\mathrm{P}$ application were partially different from those of $\mathrm{Zn}$ concentration, in line with Chen et al. (2019). When no Zn was applied, total $\mathrm{Zn}$ accumulations were significantly decreased by $\mathrm{P}$ application in all crops. The negative effects of increasing $\mathrm{P}$ application on $\mathrm{Zn}$ accumulation in oilseed rape are not consistent with Lu et al. (1998), who found that a $150 \mathrm{mg} \mathrm{P} \mathrm{kg}$ application increased shoot and root $\mathrm{Zn}$ accumulations in two oilseed rape genotypes. The reason for the disagreement may be the relatively lower $\mathrm{P}$ fertilizer application they used than 

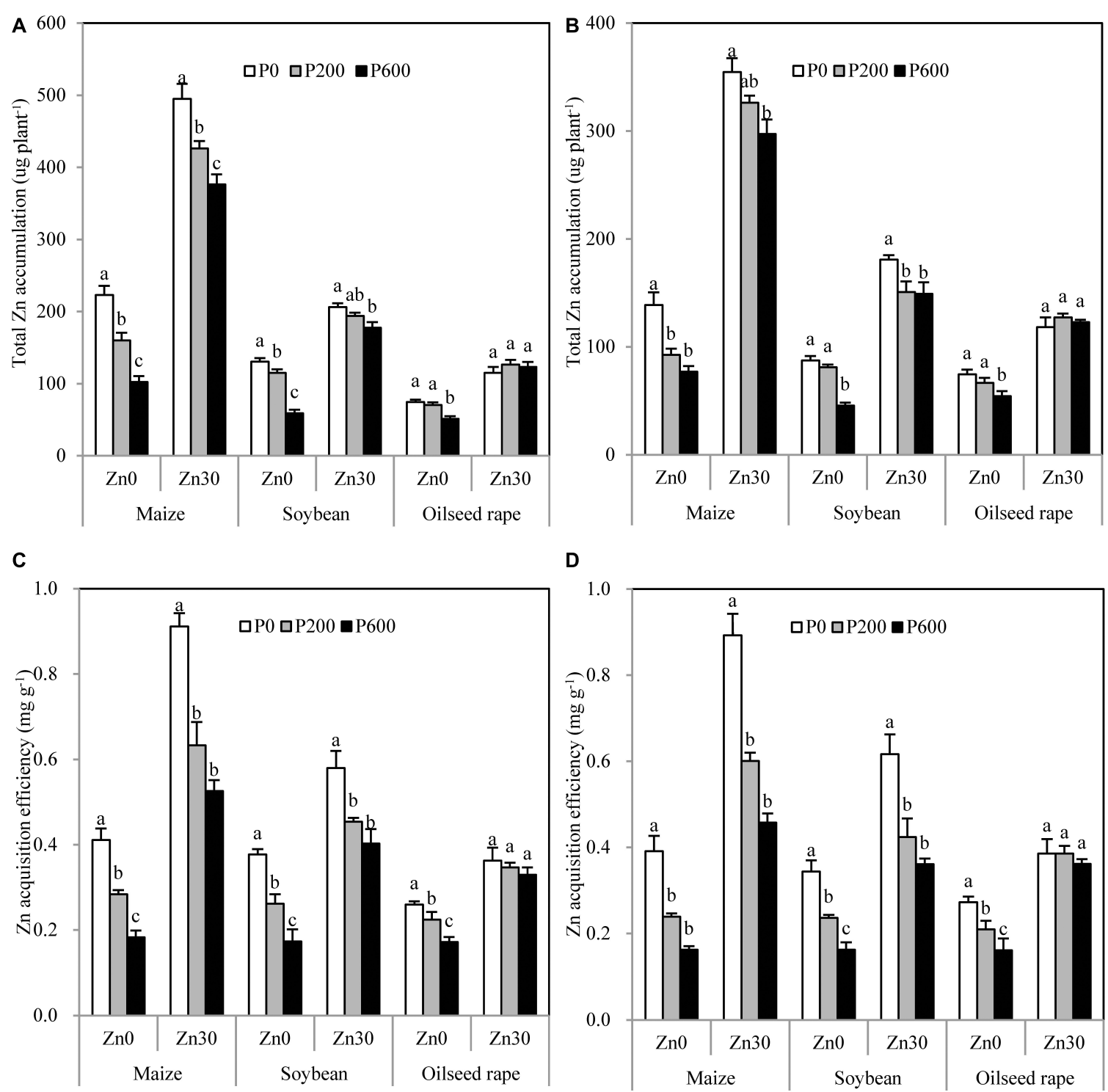

FIGURE 2 | Total Zn accumulation and Zn acquisition efficiency of maize, soybean, and oilseed rape affected by $\mathrm{P}$ and Zn applications without benomyl (A,C) and with $0.4 \mathrm{~g}$ benomyl $\mathrm{kg}^{-1}$ soil (B,D) addition, respectively. Values are means of three replications. The same lowercase letter indicates no significant difference among $\mathrm{P}$ application levels $(P<0.05)$. Zn0 and Zn30 represent 0 and $30 \mathrm{mg} \mathrm{Zn} \mathrm{kg}^{-1}$ soil rates, respectively. P0, P200, and P600 represent 0,200 , and 600 mg P kg $\mathrm{kg}^{-1}$ soil rates, respectively.

that used in the present study. Similarly, the results of a field experiment showed that the total $\mathrm{Zn}$ accumulation of wheat was increased by insufficient $\mathrm{P}$ application but decreased by excessive $\mathrm{P}$ application (Zhang W. et al., 2016). Together, these results suggest that the effects of $\mathrm{P}$ on $\mathrm{Zn}$ uptake depend on the amount of $\mathrm{P}$ supplied. $\mathrm{P}$ application also decreased the total $\mathrm{Zn}$ accumulation of maize and soybean but not of oilseed rape when $30 \mathrm{mg} \mathrm{Zn} \mathrm{kg}^{-1}$ was applied, and the degree of decrease was lower at $30 \mathrm{mg} \mathrm{Zn} \mathrm{kg}^{-1}$ than under no $\mathrm{Zn}$ addition for all crops, indicating that reasonable $\mathrm{Zn}$ fertilization can alleviate the inhibition of $\mathrm{P}$ application on crop $\mathrm{Zn}$ uptake.

Our results indicate that chemical interaction in soil was not the reason for the decrease in $\mathrm{Zn}$ uptake caused by $\mathrm{P}$ application because the soil Olsen-P concentration did not reach the critical value of $200 \mathrm{mg} \mathrm{kg}^{-1}$ (Chen et al., 2019). P application significantly increased soil DTPA-Zn concentration of maize and soybean as $\mathrm{Zn}$ applied, which is consistent with Saeed (1977) and Zhang et al. (2017a). However, no significant effect of P application on soil DTPA-Zn concentration was found for oilseed rape (Supplementary Figures 1C,D). Our results showed that $\mathrm{P}$ application had no significant effects on soil $\mathrm{pH}$ of three crops (Supplementary Figures 1A,B). Therefore, the differences in DTPA-Zn between mycorrhizal and non-mycorrhizal crops are possibly ascribed to the mobilized soil $\mathrm{Zn}$ induced by AMF hyphal exudates with P application (Kaiser et al., 2015; Zhang L. et al., 2016). Previous studies have ascribed the decrease in 
TABLE 2 | Analysis of variance for the effects of $\mathrm{P}$ application (P), Zn application (Zn), benomyl addition (B), and their interactions on Zn concentration in shoots and roots, total $\mathrm{Zn}$ accumulation, Zn acquisition efficiency, and arbuscular mycorrhizal fungi (AMF) colonization of maize, soybean, and oilseed rape, respectively.

\begin{tabular}{|c|c|c|c|c|c|c|c|c|c|c|c|c|c|c|}
\hline \multirow[t]{2}{*}{ Source } & \multicolumn{3}{|c|}{ Shoot $\mathrm{Zn}$ concentration } & \multicolumn{3}{|c|}{ Root Zn concentration } & \multicolumn{3}{|c|}{ Total $\mathrm{Zn}$ accumulation } & \multicolumn{3}{|c|}{ Zn acquisition efficiency } & \multicolumn{2}{|c|}{ AMF colonization } \\
\hline & Maize & Soybean & $\begin{array}{c}\text { Oilseed } \\
\text { rape }\end{array}$ & Maize & Soybean & $\begin{array}{c}\text { Oilseed } \\
\text { rape }\end{array}$ & Maize & Soybean & $\begin{array}{c}\text { Oilseed } \\
\text { rape }\end{array}$ & Maize & Soybean & $\begin{array}{c}\text { Oilseed } \\
\text { rape }\end{array}$ & Maize & Soybean \\
\hline$P$ level $(P)$ & $\star \star \star ~$ & $\star \star \star ~$ & $\star \star \star ~$ & $\star \star \star ~$ & 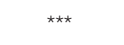 & $\star \star \star ~$ & 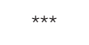 & 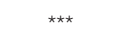 & $\star \star$ & $\star \star \star ~$ & 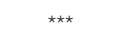 & $\star \star \star ~$ & $\star \star \star ~$ & $\star \star \star ~$ \\
\hline Zn level (Zn) & $\star \star \star$ & 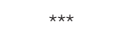 & $\star \star \star$ & $\star \star \star$ & 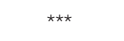 & $\star \star \star$ & 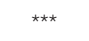 & 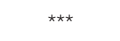 & $\star \star \star$ & $\star \star \star$ & 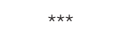 & $\star \star \star$ & $\star \star \star ~$ & 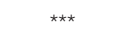 \\
\hline B level (B) & 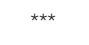 & $* \star \star *$ & ns & 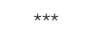 & $* * *$ & ns & 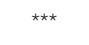 & $\star \star \star *$ & ns & * & $\star *$ & ns & 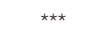 & $* \star \star *$ \\
\hline$P \times Z n$ & $\star \star \star$ & * & * & 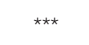 & 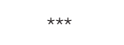 & $\star \star$ & * & 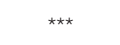 & 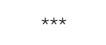 & 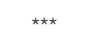 & * & ns & * & 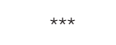 \\
\hline$P \times B$ & ns & ** & ns & ns & $\star \star$ & ns & 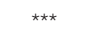 & ns & ns & ns & ns & ns & $\star \star \star \star ~$ & 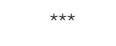 \\
\hline $\mathrm{Zn} \times \mathrm{B}$ & ns & ns & ns & ns & ns & ns & 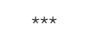 & ns & ns & ns & ns & ns & $\star \star$ & 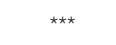 \\
\hline $\mathrm{P} \times \mathrm{Zn} \times \mathrm{B}$ & ns & ns & ns & ns & ns & ns & ns & ns & ns & ns & ns & ns & $\star \star$ & * \\
\hline
\end{tabular}

*, **, and *** significance at $P<0.05,0.01$, and 0.001 , respectively.

ns, no significance, $P>0.05$.

A

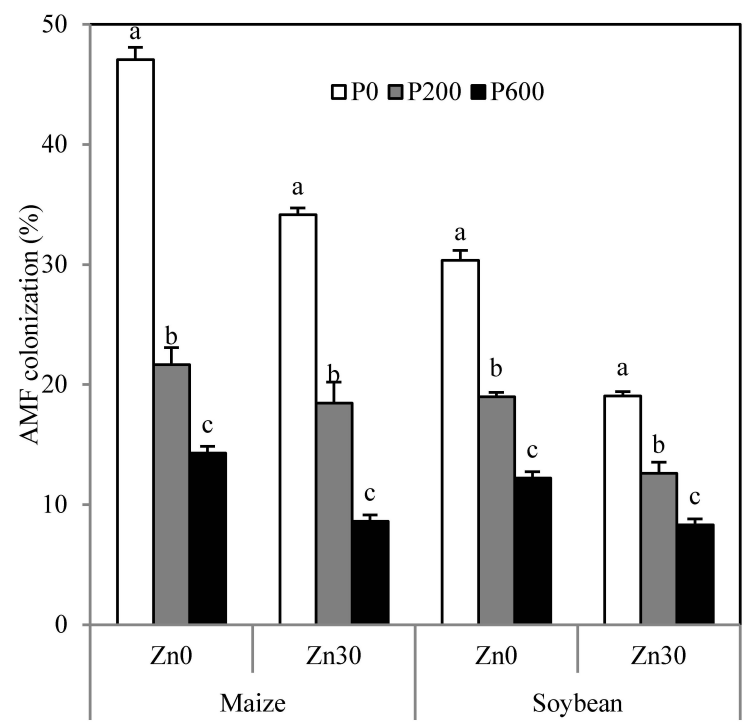

B

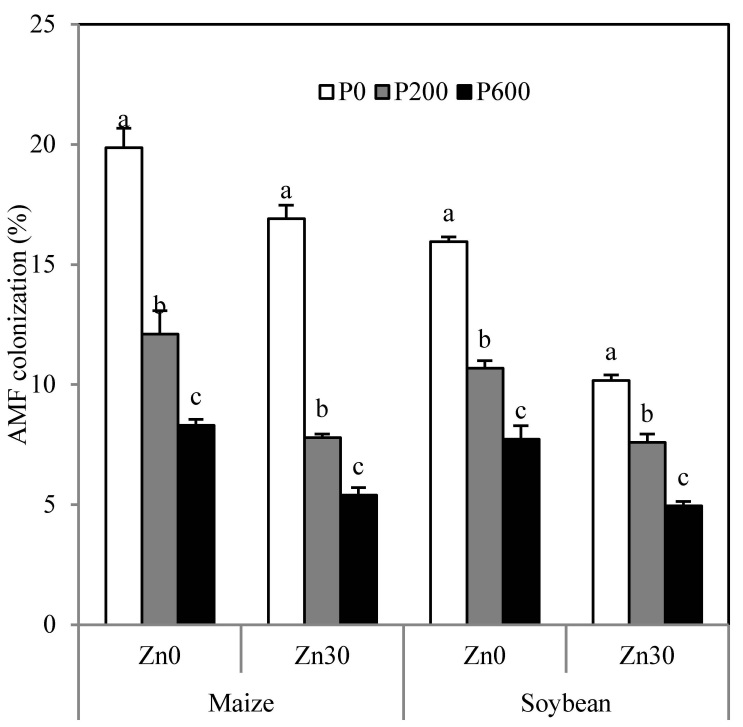

FIGURE 3 | Arbuscular mycorrhizal fungi (AMF) colonization of maize and soybean affected by $\mathrm{P}$ and Zn applications without benomyl (A) and with $0.4 \mathrm{~g}$ benomyl $\mathrm{kg}^{-1}$ soil $\mathbf{( B )}$ addition, respectively. Values are means of three replications. The same lowercase letter indicates no significant difference among $\mathrm{P}$ application levels $(P<0.05)$. Zn0 and Zn30 represent 0 and $30 \mathrm{mg} \mathrm{Zn} \mathrm{kg}^{-1}$ soil rates, respectively. $\mathrm{P0}, \mathrm{P} 200$, and P600 represent 0 , 200 , and 600 mg P kg-1 soil rates, respectively.

Zn concentration with $\mathrm{P}$ application to a "dilution effect," in which concentration decreases with biomass increase (Hui et al., 2019). However, in the current study, the shoot and root dry weights of maize, soybean, and oilseed rape did not increase as $\mathrm{P}$ application increased to $600 \mathrm{mg} \mathrm{kg}^{-1}$, in line with previous studies (Li et al., 2003; Ova et al., 2015). These results indicate that the decrease in $\mathrm{Zn}$ concentration in shoots and roots of the three crops caused by $\mathrm{P}$ application cannot simply be ascribed to the dilution effect. This was further demonstrated by the significant decrease in $\mathrm{ZnAE}$ of the three crops with increasing $\mathrm{P}$ application (Figures 2C,D), which also agrees with previous findings (Zhu et al., 2001; Zhang W. et al., 2016). Taken together, these results provide specific evidence that decreased uptake of $\mathrm{Zn}$ is a vital process in the antagonism of $\mathrm{P}$ and $\mathrm{Zn}$. However, the process of $\mathrm{Zn}$ uptake in the rhizosphere may be affected by AMF colonization, root growth, and root $\mathrm{Zn}$ concentration (Zhang et al., 2017a).

\section{Different Zn Uptake Responses Caused by $\mathbf{P}$ Application in Different Test Crops}

Although the responses of different crop species and genotypes to $\mathrm{P}$ or $\mathrm{Zn}$ application have been verified to be different (Yilmaz et al., 1997; Fageria, 2002; Watts-Williams et al., 2019; Qin et al., 2020), the negative effects of increasing P application on $\mathrm{Zn}$ uptake among different mycorrhizal and non-mycorrhizal crops have not been reported. In the present study, mycorrhizal crops (maize and soybean) displayed higher degrees of decrease in $\mathrm{Zn}$ uptake and $\mathrm{ZnAE}$ mediated by $\mathrm{P}$ application than non-mycorrhizal crop (oilseed rape). The 
TABLE 3 | Mycorrhizal Zn responsiveness of maize and soybean affected by $P$ and $\mathrm{Zn}$ applications, respectively.

\begin{tabular}{|c|c|c|c|}
\hline \multirow[b]{2}{*}{ Zn level (mg kg $\left.{ }^{-1}\right)$} & \multirow[b]{2}{*}{$P$ level $\left(\mathrm{mg} \mathrm{kg}^{-1}\right)$} & \multicolumn{2}{|c|}{$\begin{array}{c}\text { Mycorrhizal Zn } \\
\text { responsiveness (\%) }\end{array}$} \\
\hline & & Maize & Soybean \\
\hline \multirow[t]{3}{*}{0} & 0 & $61.2 \mathrm{a}$ & $50.1 \mathrm{a}$ \\
\hline & 200 & $68.4 a$ & $42.2 \mathrm{ab}$ \\
\hline & 600 & $33.5 b$ & $30.2 b$ \\
\hline \multirow[t]{3}{*}{30} & 0 & $40.0 a$ & $18.8 \mathrm{a}$ \\
\hline & 200 & $30.7 \mathrm{ab}$ & $21.0 \mathrm{a}$ \\
\hline & 600 & $26.6 b$ & $20.3 a$ \\
\hline \multicolumn{4}{|l|}{ Source of variation } \\
\hline $\mathrm{P}$ level $(\mathrm{P})$ & & 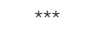 & $\star \star *$ \\
\hline Zn level (Zn) & & 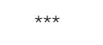 & * \\
\hline$P \times Z n$ & & $* \star$ & * \\
\hline
\end{tabular}

Values are means of three replications. Means with the same lowercase letter indicate no significant difference among $P$ application levels $(P<0.05)$.

${ }^{*},{ }^{* *}$, and ${ }^{* * *}$ significance at $P<0.05,0.01$, and 0.001 , respectively.

main reason for this difference may be that $\mathrm{P}$ application sharply decreased AMF colonization of maize and soybean, which reduced the quantity of $\mathrm{Zn}$ uptake by the mycorrhizal pathway. Analogous results were reported by Watts-Williams and Cavagnaro (2012), who found that the degree of decrease in $\mathrm{Zn}$ concentration caused by $\mathrm{P}$ application was greater in 76R (mycorrhizal genotypes of tomato) than in $r m c$ (nonmycorrhizal genotypes of tomato). In our study, between the two mycorrhizal crops, maize displayed greater decreases in $\mathrm{Zn}$ uptake and $\mathrm{ZnAE}$ in response to $\mathrm{P}$ application than soybean. This was related to AMF colonization, and the MZnR of maize was consistently higher than that of soybean (Figure 3 and Table 3).
Our path coefficient analysis results quantified the factors and the extents of influence on the $\mathrm{Zn}$ uptake of three crops caused by $\mathrm{P}$ application. Consistent with the results of total $\mathrm{Zn}$ accumulation and $\mathrm{ZnAE}$, the contributions of possible factors to the decrease in $\mathrm{Zn}$ uptake attributable to $\mathrm{P}$ application depended on whether $\mathrm{Zn}$ fertilizer was applied to the soil. AMF colonization of maize and soybean contributed most to the negative effects of higher $\mathrm{P}$ application on $\mathrm{Zn}$ uptake, explaining 89 and $69 \%$ of the effects when no $\mathrm{Zn}$ was applied and 79 and $64 \%$ at $30 \mathrm{mg} \mathrm{Zn} \mathrm{kg}^{-1}$, respectively (Table 4). The decrease in the contribution of AMF colonization at $30 \mathrm{mg} \mathrm{Zn} \mathrm{kg}^{-1}$ may be attributable to significantly decreased AMF colonization under Zn fertilization (Figure 3). Our results further demonstrate that the mycorrhizal pathway is an important factor explaining the negative effects of increasing $\mathrm{P}$ application on the $\mathrm{Zn}$ uptake of mycorrhizal crops, and that more mycorrhizal crops are affected by AMF colonization as for the antagonism of $\mathrm{P}$ on $\mathrm{Zn}$. For oilseed rape, root dry weight and root $\mathrm{Zn}$ concentration explained 90 and $92 \%$ of the decrease in $\mathrm{Zn}$ uptake at the no $\mathrm{Zn}$ and $30 \mathrm{mg} \mathrm{Zn} \mathrm{kg}^{-1}$ application levels, respectively. This indicates that root growth and development are vital factors explaining the antagonism of non-mycorrhizal crops. In addition, our results revealed that 11-12, 10-36, and 89\% of the decreases in $\mathrm{Zn}$ uptake of maize, soybean, and oilseed rape caused by $\mathrm{P}$ application, respectively, could not be explained in the present study. This implies that there are other pathways regulating $\mathrm{Zn}$ uptake as mediated by $\mathrm{P}$ application irrespective of whether the crop is mycorrhizal or non-mycorrhizal.

This study strengthens understanding of the different responses of the negative effects of higher $\mathrm{P}$ application on $\mathrm{Zn}$ concentration and $\mathrm{Zn}$ uptake of different mycorrhizal and nonmycorrhizal crops and further highlights the importance of AMF colonization in this process. Other pathways pertaining to the $\mathrm{Zn}$ uptake mediated by $\mathrm{P}$ application need to be considered in future research. In the process of crop development, different

TABLE 4 | Correlations of total Zn accumulation (dependent variable) with independent variables [root Zn concentration (RZnC), root dry weight (RDW), and arbuscular mycorrhizal fungi colonization (AMFC)] for maize, soybean, and oilseed rape when Zn was applied at 0 or $30 \mathrm{mg} \mathrm{kg}^{-1}$ soil.

\begin{tabular}{|c|c|c|c|c|c|c|c|c|c|}
\hline \multirow{2}{*}{$\begin{array}{l}\text { Zn level } \\
\left(\mathrm{mg} \mathrm{kg}^{-1}\right)\end{array}$} & \multirow{2}{*}{ Crop } & \multirow{2}{*}{$\begin{array}{c}\text { Dependent } \\
\text { variable }\end{array}$} & \multirow{2}{*}{$\begin{array}{c}\text { Independent } \\
\text { variable }\end{array}$} & \multirow{2}{*}{$\begin{array}{l}\text { Correlation } \\
\text { coefficient }\end{array}$} & \multirow{2}{*}{ Adjusted $R^{2}$} & \multirow{2}{*}{$\begin{array}{c}\text { Path } \\
\text { coefficient }\end{array}$} & \multicolumn{3}{|c|}{ Indirect path coefficients } \\
\hline & & & & & & & AMFC & RDW & $\mathrm{RZnC}$ \\
\hline \multirow[t]{6}{*}{0} & Maize & $\begin{array}{c}\text { Total Zn } \\
\text { accumulation }\end{array}$ & AMFC & 0.95 & 0.89 & 0.95 & - & & \\
\hline & Soybean & $\begin{array}{c}\text { Total Zn } \\
\text { accumulation }\end{array}$ & AMFC & 0.84 & 0.69 & 0.17 & - & 0.09 & 0.59 \\
\hline & & & RDW & 0.64 & 0.76 & 0.55 & 0.03 & - & 0.06 \\
\hline & & & $\mathrm{RZnC}$ & 0.82 & 0.90 & 0.61 & 0.16 & 0.05 & - \\
\hline & Oilseed rape & $\begin{array}{c}\text { Total Zn } \\
\text { accumulation }\end{array}$ & RDW & 0.87 & 0.75 & 0.95 & & -0.07 & - \\
\hline & & & $\mathrm{RZnC}$ & 0.35 & 0.90 & 0.49 & & - & -0.14 \\
\hline \multirow[t]{5}{*}{30} & Maize & $\begin{array}{c}\text { Total Zn } \\
\text { accumulation }\end{array}$ & AMFC & 0.90 & 0.79 & 0.96 & - & -0.06 & \\
\hline & & & RDW & 0.10 & 0.88 & 0.31 & -0.20 & - & \\
\hline & Soybean & $\begin{array}{c}\text { Total Zn } \\
\text { accumulation }\end{array}$ & AMFC & 0.80 & 0.64 & 0.80 & - & & \\
\hline & Oilseed rape & $\begin{array}{c}\text { Total Zn } \\
\text { accumulation }\end{array}$ & RDW & 0.01 & 0.79 & 1.11 & & -0.21 & - \\
\hline & & & $\mathrm{RZnC}$ & 0.89 & 0.92 & 0.49 & & - & -0.48 \\
\hline
\end{tabular}


root system architectures can form due to the soil environment, which may directly influence the nutrient acquisition capacity (Xue et al., 2014). Moreover, some Zn transporters play important roles in root uptake of $\mathrm{Zn}$, and whether this is mediated by $\mathrm{P}$ supply remains unclear. Future studies need to investigate whether and how $\mathrm{P}$ application affects root system architecture and the expressions of genes related to $\mathrm{Zn}$ uptake and root Zn uptake. Besides, though this study clarified the contribution of AMF colonization to the antagonistic interaction of $\mathrm{P}$ and $\mathrm{Zn}$ among mycorrhizal crops, there are some important points to be considered in the future. For instance, in the current study, we selected benomyl to establish different levels of AMF colonization, but it may affect various members of the soil microbial community and thus potentially influence the growth and development of crops in other ways (Rillig, 2004). Using a mycorrhiza-defective mutant is a possibility for comparing mycorrhizal and non-mycorrhizal crops in native soil without any other experimental intervention (Watts-Williams and Cavagnaro, 2015). Thus, there may be theoretical significance in quantifying the contribution of AMF colonization in this antagonistic interaction using mycorrhiza-defective mutants and their wild-type genotypes.

\section{CONCLUSION}

Three typical crops showed different responses in growth and $\mathrm{Zn}$ uptake to $\mathrm{P}$ application levels. $\mathrm{P}$ application significantly decreased the $\mathrm{Zn}$ uptake of both mycorrhizal and nonmycorrhizal crops, and the degree of reduction depended on whether the crop is mycorrhizal or non-mycorrhizal and the $\mathrm{Zn}$ supply. The decrease in $\mathrm{Zn}$ uptake of maize and soybean was mainly due to the decreased AMF colonization caused by $\mathrm{P}$ application, whereas root dry weight was significant for oilseed rape. Our results indicate that there is another pathway

\section{REFERENCES}

Bouain, N., Kisko, M., Rouached, A., Dauzat, M., Lacombe, B., Belgaroui, N., et al. (2014a). Phosphate/zinc interaction analysis in two lettuce varieties reveals contrasting effects on biomass, photosynthesis, and dynamics of pi transport. Biomed. Res. Int. 2014:548254. doi: 10.1155/2014/548254

Bouain, N., Shahzad, Z., Rouached, A., Khan, G. A., Berthomieu, P., Abdelly, C., et al. (2014b). Phosphate and zinc transport and signalling in plants: toward a better understanding of their homeostasis interaction. J. Exp. Bot. 65, 5725-5741. doi: 10.1093/jxb/eru314

Buee, M., Rossignol, M., Jauneau, A., Ranjeva, R., and Bécard, G. (2000). The presymbiotic growth of arbuscular mycorrhizal fungi is induced by a branching factor partially purified from plant root exudates. Mol. Plant Microbe Interact. 13, 693-698. doi: 10.1094/MPMI.2000.13.6.693

Cakmak, I. (2008). Enrichment of cereal grains with zinc: agronomic or genetic biofortification? Plant Soil 302, 1-17. doi: 10.1007/s11104-0079466-3

Cavagnaro, T. R. (2008). The role of arbuscular mycorrhizas in improving plant zinc nutrition under low soil zinc concentrations: a review. Plant Soil 304, 315-325. doi: 10.1007/s11104-008-9559-7

Chen, X., Zhang, W., Wang, Q., Liu, Y., Liu, D., and Zou, C. (2019). Zinc nutrition of wheat in response to application of phosphorus to a calcareous soil and an acid soil. Plant Soil 434, 139-150. doi: 10.1007/s11104-0183820-5 regulating $\mathrm{Zn}$ uptake mediated by $\mathrm{P}$ supply in addition to the mycorrhizal pathway.

\section{DATA AVAILABILITY STATEMENT}

The raw data supporting the conclusions of this article will be made available by the authors, without undue reservation.

\section{AUTHOR CONTRIBUTIONS}

B-GY contributed to resources, data curation, and writing of the original draft. X-XC contributed to investigation. W-QC contributed to investigation. Y-ML contributed to investigation. C-QZ contributed to conceptualization, writing, review, and editing. All authors contributed to the article and approved the submitted version.

\section{FUNDING}

This work was funded by the National Natural Science Foundation of China (NSFC 31272252), an Innovative Group Grant of the NSFC (no. 31421092), and the Deutsche Forschungsgemeinschaft (DFG, German Research Foundation)328017493/GRK 2366 (Sino-German International Research Training Group AMAIZE-P).

\section{SUPPLEMENTARY MATERIAL}

The Supplementary Material for this article can be found online at: https://www.frontiersin.org/articles/10.3389/fpls.2020. 606472/full\#supplementary-material

Chen, X., Zhang, Y., Tong, Y., Xue, Y., Liu, D., Zhang, W., et al. (2017). Harvesting more grain zinc of wheat for human health. Sci. Rep. 7:7019. doi: 10.1038/ s41598-017-07484-2

Chu, Q., Zhang, L., Zhou, J., Yuan, L., Chen, F., Zhang, F., et al. (2020). Soil plantavailable phosphorus levels and maize genotypes determine the phosphorus acquisition efficiency and contribution of mycorrhizal pathway. Plant Soil 449, 357-371. doi: 10.1007/s11104-020-04494-4

Cihacek, L. J., Carcoana, R., and Jacobson, K. (1993). Phosphorus and zinc fertilization effects on dry matter yield and phosphorus and zinc uptake by crambe. J. Plant Nutr. 16, 1829-1836. doi: 10.1080/01904169309364653

Fageria, N. K. (2002). Micronutrients' influence on root growth of upland rice, common bean, corn, wheat, and soybean. J. Plant Nutr. 25, 613-622. doi: 10.1081/PLN- 120003385

Fitter, A. H., and Nichols, R. (1988). The use of benomyl to control infection by vesicular-arbuscular mycorrhizal fungi. New Phytol. 110, 201-206. doi: 10.1111/ j.1469-8137.1988.tb00253.x

Gao, X., Kuyper, T. W., Zou, C., Zhang, F., and Hoffland, E. (2007). Mycorrhizal responsiveness of aerobic rice genotypes is negatively correlated with their zinc uptake when nonmycorrhizal. Plant Soil 290, 283-291. doi: 10.1007/s11104006-9160-x

Hoeksema, J. D., Chaudhary, V. B., Gehring, C. A., Johnson, N. C., Karst, J., Koide, R. T., et al. (2010). A meta-analysis of context-dependency in plant response to inoculation with mycorrhizal fungi. Ecol. Lett. 13, 394-407. doi: 10.1111/j.1461-0248.2009.01430.x 
Hui, X., Luo, L., Wang, S., Cao, H., Huang, M., Shi, M., et al. (2019). Critical concentration of available soil phosphorus for grain yield and zinc nutrition of winter wheat in a zinc-deficient calcareous soil. Plant Soil 444, 315-330. doi: 10.1007/s11104-019-04273-w

Izsáki, Z. (2014). Effects of phosphorus supplies on the nutritional status of maize (Zea mays L.). Commun. Soil Sci. Plan. Anal. 45, 516-529. doi: 10.1080/ 00103624.2013 .863910

Kaiser, C., Kilburn, M. R., Clode, P. L., Fuchslueger, L., Koranda, M., Cliff, J. B., et al. (2015). Exploring the transfer of recent plant photosynthates to soil microbes: mycorrhizal pathway vs direct root exudation. New Phytol. 205, 1537-1551. doi: $10.1111 /$ nph. 13138

Koske, R., and Gemma, J. (1989). A modified procedure for staining roots to detect VA mycorrhizas. Mycol. Res. 92, 486-488. doi: 10.1016/S0953-7562(89)80195-9

Lehmann, A., Veresoglou, S. D., Leifheit, E. F., and Rillig, M. C. (2014). Arbuscular mycorrhizal influence on zinc nutrition in crop plants - a meta-analysis. Soil Biol. Biochem. 69, 123-131. doi: 10.1016/j.soilbio.2013.11.001

Li, H. Y., Zhu, Y. G., Smith, S. E., and Smith, F. A. (2003). Phosphorus-zinc interactions in two barley cultivars differing in phosphorus and zinc efficiencies. J. Plant Nutr. 26, 1085-1099. doi: 10.1081/PLN-120020077

Lindsay, W., and Norvell, W. (1978). Development of a DTPA soil test for zinc, iron, manganese, and copper. Soil Sci. Soc. Am. J. 42, 421-428. doi: 10.2136/ sssaj1978.03615995004200030009x

Lu, Z., Grewal, H. S., and Graham, R. D. (1998). Dry matter production and uptake of zinc and phosphorus in two oilseed rape genotypes under differential rates of zinc and phosphorus supply. J. Plant Nutr. 21, 25-38. doi: 10.1080/ 01904169809365380

McGonigle, T. P., Miller, M. H., Evans, D. G., Fairchild, G. L., and Swan, J. A. (1990). A new method which gives an objective measure of colonization of roots by vesicular-arbuscular mycorrhizal fungi. New Phytol. 115, 495-501. doi: 10.1111/j.1469-8137.1990.tb00476.x

Olsen, S. R. (1954). Estimation of Available Phosphorus in Soils by Extraction with Sodium Bicarbonate. Washington, DC: U.S. Department of Agriculture. 1-19.

Ova, E. A., Kutman, U. B., Ozturk, L., and Cakmak, I. (2015). High phosphorus supply reduced zinc concentration of wheat in native soil but not in autoclaved soil or nutrient solution. Plant Soil 393, 147-162. doi: 10.1007/s11104-0152483-8

Qiao, Y., Bai, Y., Zhang, Y., She, W., Lai, Z., and Qin, S. (2019). Arbuscular mycorrhizal fungi shape the adaptive strategy of plants by mediating nutrient acquisition in a shrub-dominated community in the Mu Us Desert. Plant Soil 443, 549-564. doi: 10.1007/s11104-019-04253-0

Qin, J., Wang, H., Cao, H., Chen, K., and Wang, X. (2020). Combined effects of phosphorus and magnesium on mycorrhizal symbiosis through altering metabolism and transport of photosynthates in soybean. Mycorrhiza 30, 285298. doi: 10.1007/s00572-020-00955-x

Rillig, M. (2004). Arbuscular mycorrhizae, glomalin, and soil aggregation. Can. J. Soil Sci. 84, 355-363. doi: 10.4141/S04-003

Saeed, M. (1977). Phosphate fertilization reduces zinc adsorption by calcareous soils. Plant Soil 48, 641-649. doi: 10.1007/BF00145774

Shahzad, Z., Rouached, H., and Rakha, A. (2014). Combating mineral malnutrition through iron and zinc biofortification of cereals. Compr. Rev. Food Sci. Food Saf. 13, 329-346. doi: 10.1111/1541-4337.12063

Singh, J., Karamanos, R., and Stewart, J. (1986). Phosphorus-induced zinc deficiency in wheat on residual phosphorus plots. Agron. J. 78, 668-675. doi: 10.2134/agronj1986.00021962007800040023x

Smith, S. E., Smith, F. A., and Jakobsen, I. (2003). Mycorrhizal fungi can dominate phosphate supply to plants irrespective of growth responses. Plant Physiol. 133, 16-20. doi: 10.1104/pp.103.024380

Stukenholtz, D., Olsen, R., Gogan, G., and Olson, R. (1966). On the mechanism of phosphorus-zinc interaction in corn nutrition. Soil Sci. Soc. Am. J. 30, 759-763. doi: 10.2136/sssaj1966.03615995003000060029x

Tawaraya, K. (2003). Arbuscular mycorrhizal dependency of different plant species and cultivars. Soil Sci. Plant Nutr. 49, 655-668. doi: 10.1080/00380768.2003. 10410323

Tran, B. T. T., Watts-Williams, S. J., and Cavagnaro, T. R. (2019). Impact of an arbuscular mycorrhizal fungus on the growth and nutrition of fifteen crop and pasture plant species. Funct. Plant Biol. 46:732-742. doi: 10.1071/FP18327

Watts-Williams, S. J., and Cavagnaro, T. R. (2012). Arbuscular mycorrhizas modify tomato responses to soil zinc and phosphorus addition. Biol. Fert. Soils 48, 285-294. doi: 10.1007/s00374-011-0621-x
Watts-Williams, S. J., and Cavagnaro, T. R. (2015). Using mycorrhiza-defective mutant genotypes of non-legume plant species to study the formation and functioning of arbuscular mycorrhiza: a review. Mycorrhiza 25, 587-597. doi: 10.1007/s00572-015-0639-2

Watts-Williams, S. J., Jewell, N., Brien, C., Berger, B., Garnett, T., and Cavagnaro, T. R. (2019). Using high-throughput phenotyping to explore growth responses to mycorrhizal fungi and zinc in three plant species. Plant Phenomics 2019, 1-12. doi: 10.34133/2019/5893953

Watts-Williams, S. J., Patti, A. F., and Cavagnaro, T. R. (2013). Arbuscular mycorrhizas are beneficial under both deficient and toxic soil zinc conditions. Plant Soil 371, 299-312. doi: 10.1007/s11104-013-1670-8

WHO (2016). WHO Guideline: Use of Multiple Micronutrient Powders for Point-ofUse Fortification of Foods Consumed by Infants and Young Children Aged 6-23 Months and Children Aged 2-12 Years. Geneva: World Health Organization.

Xue, Y., Zhang, W., Liu, D., Yue, S., Cui, Z., Chen, X., et al. (2014). Effects of nitrogen management on root morphology and zinc translocation from root to shoot of winter wheat in the field. Field Crop Res. 161, 38-45. doi: 10.1016/j. fcr.2014.01.009

Yang, G., Liu, N., Lu, W., Wang, S., Kan, H., Zhang, Y., et al. (2014). The interaction between arbuscular mycorrhizal fungi and soil phosphorus availability influences plant community productivity and ecosystem stability. J. Ecol. 102, 1072-1082. doi: 10.1111/1365-2745.12249

Yang, X., Tian, X., Lu, X., Cao, Y., and Chen, Z. (2011). Impacts of phosphorus and zinc levels on phosphorus and zinc nutrition and phytic acid concentration in wheat (Triticum aestivum L.). J. Sci. Food Agric. 91, 2322-2328. doi: 10.1002/ jsfa.4459

Yilmaz, A., Ekiz, H., Torun, B., Gultekin, I., Karanlik, S., Bagci, S. A., et al. (1997). Effect of different zinc application methods on grain yield and zinc concentration in wheat cultivars grown on zinc-deficient calcareous soils. Plant. Nutr. 20, 461-471. doi: 10.1080/01904169709365267

Zhang, L., Xu, M., Liu, Y., Zhang, F., Hodge, A., and Feng, G. (2016). Carbon and phosphorus exchange may enable cooperation between an arbuscular mycorrhizal fungus and a phosphate-solubilizing bacterium. New Phytol. 210, 1022-1032. doi: 10.1111/nph.13838

Zhang, W., Chen, X., Liu, Y., Liu, D., Chen, X., and Zou, C. (2017a). Zinc uptake by roots and accumulation in maize plants as affected by phosphorus application and arbuscular mycorrhizal colonization. Plant Soil 413, 59-71. doi: 10.1007/ s11104-017-3213-1

Zhang, W., Liu, D., Li, C., Chen, X., and Zou, C. (2017b). Accumulation, partitioning, and bioavailability of micronutrients in summer maize as affected by phosphorus supply. Eur. J. Agron. 86, 48-59. doi: 10.1016/j.eja.2017.03.005

Zhang, W., Liu, D., Li, C., Cui, Z., Chen, X., Russell, Y., et al. (2015). Zinc accumulation and remobilization in winter wheat as affected by phosphorus application. Field Crop Res. 184, 155-161. doi: 10.1016/j.fcr.2015.10.002

Zhang, W., Liu, D., Liu, Y., Cui, Z., Chen, X., and Zou, C. (2016). Zinc uptake and accumulation in winter wheat relative to changes in root morphology and mycorrhizal colonization following varying phosphorus application on calcareous soil. Field Crop Res. 197, 74-82. doi: 10.1016/j.fcr.2016.08.010

Zhang, Y., Deng, Y., Chen, R., Cui, Z., Chen, X., Yost, R., et al. (2012). The reduction in zinc concentration of wheat grain upon increased phosphorusfertilization and its mitigation by foliar zinc application. Plant Soil 361, 143-152. doi: 10.1007/s11104-012-1238-Z

Zhu, Y., Smith, S., and Smith, F. (2001). Zinc (Zn)-phosphorus (P) interactions in two cultivars of spring wheat (Triticum aestivum L.) differing in $\mathrm{P}$ uptake efficiency. Ann. Bot. 88, 941-945. doi: 10.1006/anbo.2001.1522

Zou, C. Q., Zhang, Y. Q., Rashid, A., Ram, H., Savasli, E., Arisoy, R. Z., et al. (2012). Biofortification of wheat with zinc through zinc fertilization in seven countries. Plant Soil 361, 119-130. doi: 10.1007/s11104-012-1369-2

Conflict of Interest: The authors declare that the research was conducted in the absence of any commercial or financial relationships that could be construed as a potential conflict of interest.

Copyright (c) $2020 \mathrm{Yu}$, Chen, Cao, Liu and Zou. This is an open-access article distributed under the terms of the Creative Commons Attribution License (CC BY). The use, distribution or reproduction in other forums is permitted, provided the original author(s) and the copyright owner(s) are credited and that the original publication in this journal is cited, in accordance with accepted academic practice. No use, distribution or reproduction is permitted which does not comply with these terms. 